\title{
Environmental, Public Health and Socio- Economic Issues of Oil Spillage in Niger Delta, Nigeria
}

\author{
Muhammad Tariq Bashir \\ Department of Civil Engineering, \\ Jouf University, Saudi Arabia
}

\begin{abstract}
This paper critically reviewed the prevailing socioeconomic trends in the Niger-Delta, Nigeria and concludes consequences of socio-economical disequilibrium, public health and environmental issues due to oil spillage. Niger Delta is a densely populated region in the sub-Saharan Africa and described as the engine room that drives economic growth and development in Nigeria as up to $80 \%$ of the Nigerian economic growth stems from this region. This region bears on the nation's economy but development is skewed to its disfavor owing to the public policies that are frequently in disfavor of the people. Multinational oil companies explored fossil fuel blandly and thereby curtailed the sustainability of the environment. On the hand, Nigerian government has taken some remarkable steps and employed different methods to mitigate spillages. Contrarily, studies indicate the failure of the law and weakness of the government to enforce the law catalyzed by corruption.
\end{abstract}

Keywords: Environmental Ecology, Crude Oil, Oil Spills, Environmental Degradation, Oil Spill Policy

\section{INTRODUCTION}

Niger Delta is a densely populated region in the subSaharan Africa that makes up nearly $8 \%$ of the Nigeria's landmass. The region makes up 70,000 square kilometers comprising eight states which include Delta, Bayelsa, Rivers, Edo, Cross Rivers, Akwa-Ibom Abia, and Ondo. The Niger Delta is an array of geographically contiguous states and convenient political nomenclature for resource allocation and distribution among the aforementioned states [1,2].Jike (2004) also described it as the engine room that drives economic growth and development in Nigeria as up to $80 \%$ of the Nigerian economic growth stems from this region. Irrespective of the immense relevance this region bears on the nation's economy, development is skewed to its disfavor owing to the public policies that are frequently in disfavor of the people. Moreover, oil spillage and environmental degradation characterize this region, obvious opposite to what is expected of an economic and development engine room.

\section{BRIEF HISTORY OF CRUDE OIL}

The history of crude oil in the world is well documented. Crude oil has been known for thousands of years, but its relevance and uses were not apparent. It was basically recognized for the fact that it can burn well and was often used for incendiary weapons and hair dressing $[3,4]$. It was not until the 19th century that crude oil was discovered using modern drilling technology used in the search for water [3]. The technique for processing crude oil in order to produce kerosene for illumination was discovered as early as the 19th century and towards the end of the 19th century, electricity was discovered.

Prior to the utilization of crude oil, whale oil was used for illumination, but whaling was not the cheap, safe or efficient way of getting fuel. On the contrast, crude oil provides cheap and efficient fuel for transportation. The discovery of crude oil and its immense benefits catalyzed development leading to the construction of modern shipping, railways, and roads. This also brought about diesel engines for trains, big trucks and internal combustion engines using gasoline [3]. Undeniably, the industrial revolution would not be possible without the discovery of crude oil. Crude oil was discovered in Nigeria in 1956 by Shell British Petroleum (now Royal Dutch Shell) at Oloibiri, a village in Bayelsa State, located within the Niger Delta in Nigeria and consequently, in 1958, the commercial production of crude oil began [5]. At onset of its discovery, the production of Shell was 51,000 barrels per day. The quantity doubled in the following year and in 1979 (20 years after), the rate of crude oil production attained a peak of 2.44 million barrels per day. However, due to agreements with the Organization of Petroleum Exporting Countries abbreviated as OPEC, crude oil production has been maintained at 1.5 million barrels per day. Today, 10 international oil companies are responsible for crude oil production in Nigeria. These companies work at a total of 122 fields that contain more than 970 oil wells $[6,7]$

\section{CRUDE OIL AND THE NIGERIAN ECONOMY}

Oil and gas are the foremost backbones to the Nigeria economy. Before the discovery of oil in 1956, the Nigeria's economy was agricultural-centric. Sadly, since oil discovery, attention has been shifted from agriculture and another source of revenue to oil wells [7]. According to Jike (2004, the sequel to the discovery of oil in Nigeria, the country started a novel exploration of this natural resource that raised its citizenry and a great number of people labeled oil as black gold [1]. However, he indicated that time has proved many people wrong in naming oil as black gold. This is because the discovery of oil has not positively affected the general livelihood of the people. Moreover, Odeyemi \& Ogunseitan (1985) pointed out that oil revenue supports the Nigeria's economy remarkably as it provides up to $90 \%$ of foreign exchange earnings and $85 \%$ of the 
total government revenue [7]. Remarkably, NNPC (1982) stated that crude oil in Nigeria would maintain its importance probably until its reserves dry up. The continued dependence on crude oil by the country has done it more harm than good [8]. Nigeria endured a period of an oil boom which was wasted on white elephant projects and irrelevant projects. As a matter of fact, the increased tension in the economy in the recent times is a clear aftermath of the misused oil boom.

\section{OIL SPILLAGE IN NIGER DELTA}

Indeed, the oil industry located in Niger Delta has contributed immensely to the growth and development of the country. However, the unsustainable oil exploration practices over the years in this region of the country has rendered it as one of the five most prominent and severe petroleum damaged ecosystems on the globe. This is made more obvious on considering the fact that the quantity of oil spilled over some 50 years ago in this region was more than 9 - 13 million barrels. This is equivalent to 50 Exxon Valdez spills. The result of this is severe damage of farm lands, pollution of lands, threatening of aquatic life, unemployment, flood and the like. In fact, most ablebodied young men in Niger Delta has lost their means of livelihood primarily because of the fact that the intermittent oil spillages rendered vast stretches of the indigenous farmlands useless $[1,3]$.

Numerous oil spillage disasters have been witnessed in the Niger Delta. The Egbema spillage disaster that took place in Egbema, Delta State, was thought to be severe. However, few years after this particular incident, an avalanche of more devastating oil spillage disasters have been witnessed in Jesse Oviri-Court, Evwereni, and Ekakpamre (all in Delta State). Furthermore, the Eket oil spillage in Akwa Ibom state is also a significant oil disaster that caused severe environmental degradation in the region [1]. Perhaps the most appalling of it all is that the government and the multinational oil companies involved do little to mitigate the effect of these disasters on the local people and the aftermath, and negative consequences it brings are being borne by the people resulting to hunger, disease, unemployment as well as war, violence, and conflicts.

Kadafa (2012) reported that the first oil spill in Nigeria occurred at Araromi in the present Ondo State in 1908 [5]. The Forcados oil spill that took place in Delta State in which Forcados tank spilled 570,000 barrels of oil into the Forcardo estuary occurred in 1979. Another remarkable oil spills is the Funiwa Field blowout in which an estimate of 421,000 barrels of oil spilled was reported into the ocean during a period of 17 th to 30th January in 1980. The Oyakama oil spillage that took place on 10th of May 1980 is another major spill involving about 30,000 bbl. In August 1983, the Ebocha-Brass pipeline spilled over 5000 barrels of oil in Oshika village and the oil flooded the lakes and swamped forest [5].

According to Amnesty International (2015) [9], Royal Dutch Shell and ENI, an Italian multinational oil giant, admitted more than 550 oil spills incidents in the Niger Delta in 2014. This figure is quite high in comparison to the number of spills recorded in Europe during the period of 1971- 2011 which averages 10 spills per year. Shell reported about 204 spills while ENI reported 349 spills in 2014. The high oil spill data would have been taken as a national emergency in any other country but in Nigeria, it seems to be a standard procedure for operation and the resultant pollution costs the people greatly. ENI, which seemed to be a small player in the Niger Delta than Shell, has even contributed more to the oil spill. The reported number of oil spills from this oil company requires urgent action from both the Nigerian and the Italian government. Besides the 349 oil spills reported by the company in 2014, ENI had already over 500 oil spills in 2013 and up to 474 oil spills was reported by this company in 2012 [9] .

\section{CAUSES OF OIL SPILLAGE IN THE DELTA}

The major causes of oil spills in the Niger Delta are well documented. Primary among these are blow outs, vandalism, equipment malfunction, corrosion, accidental and deliberate releases and some other natural causes. The Department of Petroleum Resources (DPR) argues that up to $88 \%$ of the oil spills occur due to the failure of the equipment used in the exploration process and transportation [10,11]. NOSDRA (2008) stressed that oil pipelines and storage facilities failure in Nigeria are the major causes of oil spillage. Interestingly, various factors can lead to the damage and leakage of pipelines, and these factors include pipe corrosion from ground erosion, material defects, tectonic movements in the bottom of the sea and contact with ship anchors. Moreover, vandalism is also identified as a major cause of pipeline damage, but its impact bears much significance in onshore regions [11]. Pipeline vandalism as identified by NOSDRA (2008) occurs mostly through an act of sabotage, implying acts that interrupt the distribution and production of petroleum products. This is the primary cause of oil spillage in the country today. This usually occurs due to attacks by thieves who seek to siphon fuel and usually such act lead to a frequent explosion and outbreak of pipeline fire [11].

\section{IMPACTS OF OIL SPILLAGE}

Needless to say, oil spillage has had grave negative consequences on Nigeria and most especially Niger Delta. Its negative impacts are far-reaching including environmental, public health and socio-economic impact to mention a few.

\subsection{Environmental Impact}

Perhaps the most saddening of all the oil spill impacts in the Niger Delta is the environmental impact. According to Kadafa, (2012) [5], the Niger Delta is made up of diverse ecosystems of mangrove swamps, freshwater swamps, and rainforests. In fact, that is one of the largest wetlands in Africa as well as one of the ten most important wetlands in the global marine ecosystems. However, the pollution due to oil spillage has gone a long way in transforming it to an inky blackness. As a matter of fact, the area is now so polluted that contaminated streams and rivers as well as loss of biodiversity and the destruction of forests characterize it. The author is right to call it an ecological wasteland. Moreover, the type of the oil, the 
volume of the spill, duration of re-oiling, the extent of oil coverage on exposed roots along with the degree of substrate oiling all determine the damage caused by oil spillage on the mangrove. The toxicity of the oil is also an issue of concern. Light oil may be considered acutely toxic but heavier oil can smother people and could lead to death [5].

In fact, the effect of oil spillage on the Niger Delta environment can be well summarized in the word 'environmental degradation.' Snowden \& Ekweozor (1987) painted a clearer picture as it cites the effects of the Bonny Estuary spillage of 1984 [12]. The data gathered from the spillage indicated that there was almost total elimination of the littoral infauna and a highly significant oyster mortality at the spill site. Furthermore, there was a $30 \%$ oiling of mangrove prop roots and $32 \%$ oiling of seedlings within a 500 square meters area. However, the Bonny Estuary spillage described by Snowden \& Ekweozor (1987) was considered minor as per the quantity of oil spill, the effect observed and the ecological significance. Nevertheless, it bears much relevance as its impact on the environment is indeed significant. Major oil spills by far affect the environment, destroying aquatic life, degrading the environment and causing the loss of lives [12].

\subsection{Impact on Public Health}

The oil spillage in Niger Delta has grave health implications [13]. This is because the spills contaminate the surface water, ambient air, ground water and crops with hydrocarbons and carcinogens such as benxo(a)pyrene and polycyclic aromatic hydrocarbon, radioactive elements that occur naturally and besides trace metals can further bioaccumulate in food crops. This could lead to about $60 \%$ reduction in household food security and could also reduce the ascorbic acid content of vegetables and crude protein content of cassava by $36 \%$ and $40 \%$ respectively. The result of this could be a $24 \%$ increase in the occurrence of childhood malnutrition. Moreover, given the nature of the Nigerian crude oil as hemotoxic and hepatoxic, crude oil spillage in the Niger Delta could also lead to cancer and infertility. In general, crude oil spills in the Niger Delta have long-term and acute effects on the human health [13].

Besides, sea animals are usually the first to face the brunt of oil spillage and as a result, many aquatic lives are destroyed as a result of oil spillage. Moreover, the massive genocide of aquatic animals causes pollution, and there is an enormous health risk linked to the consumption of the contaminated sea food. Odeyemi \& Ogunseitan (1985) reported an oil spill that took place in 1984 at a creek town called Otujeremi in the suburbs of the Shell Petroleum Development Company oil field. The oil leakage was undiscovered for up to 6 days and during this time a substantial amount of oil had spilled. The result of this on the public health was enormous as it led to the deterioration of the health condition of the Otujeremi people as it paralyzed the marine life and stunted the growth of the cassava plantations. The villagers could not access treated water. Consequently, they had no choice than to drink from dirty wells which led to varieties of diseases [13].

\subsection{Socio-Economic Impacts}

To examine the socio-economic impacts of oil spills, it is imperative to consider that oil spills impact the environment and human health in many negative ways as discussed above. These effects lead to numerous socioeconomic impacts. It will interest one to note that the socio-economic impacts of the oil spill are really multidimensional and contribute a lot to most of the insurgencies in the Niger Delta and Nigeria at large. Numerous socioeconomic impacts of oil spillage are well documented [14]. Okonkwo (2014) pointed out that these socio-economic impacts include the damage of farmlands, prostitution and rape, impacts of traditional institutions of authority on cultural values, conflicts, destruction of cultural areas and spirituality, destruction of communities as well as forced displacement, migration, and environmental refugees. In addition, it includes the vandalism of oil facility, kidnapping, and terrorism, food shortage and hunger, destruction of traditional means of livelihood and unemployment, loss of income and damage of fisheries and wildlife [14]. Okonkwo (2014) further stressed that these socio-economic impacts are truly glaring but the law is quite ineffective in tackling them. The result is violence and remarkable negative impact on the economy in general as well as the socio wellbeing of the people [14].

\section{MANAGEMENT TACTICS AND METHODS FOR REDUCTION OF OIL SPILLAGES}

The Nigerian government has taken some remarkable steps and employed different methods to mitigate spillages. Various laws and legislations have been put in place against pipeline vandalism and oil spillage by various means in order to mitigate the issue even though its success has not been significant. Moreover, offenders and conspirers have been labeled capital punishment, and laws have been passed against crude oil spillage by multinational oil companies. However, it is pertinent to take a closer look at some of the steps that were taken by the government over the years against oil spillage.

\subsection{Legislative Frameworks Put in Place by The Government}

A number of laws have been put in place to govern the petroleum industry in Nigeria and these laws also encompass oil spill management. These policies according to NOSDRA (2008) include the oil pipeline act of 1965 , the mineral oil (safety) regulations of 1997, the petroleum regulations of 1967 , the petroleum drilling and production regulations of 1969, the oil in navigable water act of 1968, the oil terminal dues act of 1969 , the petroleum refining regulations of 1974, the federal environment regulations of 1974, the federal environmental protection agency act of 1990 , the national oil spill detection and response agency act of 2006 and the Ministry of Niger Delta. Moreover, another moves by the Nigerian government in fighting oil spillage is being a signatory of the International Convention of Oil Pollution, Preparedness and Response Co-operation (OPRC). The organization aims at ensuring that the member states develop a national system or plan that would aid it in promptly or effectively responding to 
the incidence of oil pollution. Moreover, the Nigerian government developed a National Oil Spill Contingency Plan (NOSCP) as a measure to meet up with its OPRC objectives. Furthermore, the national oil spill detection and response agency was also established by the federal government of Nigeria as a measure to meet its OPRC objectives [11].

However, Nwoko (2014) did not mince words in asserting that one of the problems of the developing country like Nigeria is the inherent government failures in legal enforcement [15]. Moreover, he further pointed out that the petroleum companies are also not able to comply with petroleum-related legislation in the country. This is the major reason for the repeated failure by the government to effectively mitigate and drastically reduce the oil spillage in Nigeria Delta and Nigeria at large. In lieu of this, there have been an increase in armed attacks on the Nigeria oil industry and a massive expansion of oil theft which Nwajiaku-Dahou (2012) rightly called a political war [16]. It obviously cannot be argued that the apathetic attitudes of the Nigerian government in dealing with the oil spillage and oil management issues are the major reasons for the increased possibility of rebel participation among youths living in the Niger Delta of Nigeria [17] (Oyefusi, 2008). According to Okonkwo (2014) [14], the reason for the failure of the law includes corruption, conflicting roles, weak penalties, enforcement problems and so forth. Furthermore, the government should review spill response procedure, ensure independent monitoring, amend laws, improve enforcement initiatives and better clarify institutional roles.

\subsection{Management Plan and Methods Leveraged to Prevent Oil Spillage}

The vandalism of oil pipelines by far appears to be the commonest means of oil spillage. The federal government of Nigeria has put immense effort to mitigate this challenge. According to Nwilo \& Badejo (2015), through an act of the National Assembly, the Federal Government of Nigeria created the Niger Delta Development Commission (NDDC) which has a responsibility of developing a master plan for the development of Niger Delta and provision of infrastructure [18]. Moreover, several mechanical, chemical and biological oil spill cleaning methods have been developed and leveraged by the Nigerian government in order to effectively manage oil spill problem. These methods involve bioremediation by different species of plants [19] and oil spill models 9[18] that have extensively been used to manage oil spills on the Nigerian Coast. Most interestingly, the Nigerian government has developed standards for the development of the environmental sensitivity index maps for the Niger Delta through the Environmental System Research Institute. Multinational oil companies operating in Nigeria use this standard to prepare ESI maps for their operating areas.

\section{CONCLUSION}

Oil spillage is indeed a global issue, but obviously, it is on its high side in the Niger Delta. Studies indicate that the failure of the law and weakness of the government to enforce the law catalyzed by corruption are the major reasons for this problem. The oil spillage in Niger Delta is causing a lot of environmental, public health and socioeconomic problems as evident in the present day Niger Delta and Nigeria at large. The ball rests in the court of both the government and the multinational oil industries concerned to mitigate these issues.

\section{REFERENCES}

[1] V. Jike, "Environmental Degradation, Social Disequilibrium, and the Dilemma of Sustainable Development in the NigerDelta of Nigeria", Journal of Black Studies, vol. 34, no. 5, pp 686-701, 2004. Available: 10.1177/0021934703261934.

[2] Effect of Oil Spillage on Groundwater Quality", Journal of Environmental Studies, vol. 3, no. 1, pp. 1-3, 2017. Available: 10.13188/2471-4879.1000019.

[3] F. Leverett, Reading Seminar in Social Science: The Geopolitics and Geoeconomics of Global Energy, 1st ed. 2007.

[4] M. Uwem Useh, "Physicochemical and Bacteriological Analysis of Sludge and Water contaminated by Oil Spillage in Some Coastal Communities of Akwa Ibom State, Nigeria", Advances in Applied Sciences, vol. 2, no. 5, p. 64, 2017. Available: 10.11648/j.aas.20170205.12.

[5] A. Kadafa, "Environmental Impacts of Oil Exploration and Exploitation in the Niger Delta of Nigeria", Global Journal of Science Frontier Research Environment \& Earth Sciences, vol. 12, no. 2012. Available: https://globaljournals.org/GJSFR_Volume12/2-EnvironmentalImpacts-of-Oil-Exploration.pdf.

[6] N. F and O. N, "Wireless Sensor Networks based Pipeline Vandalisation and Oil Spillage Monitoring and Detection: Main Benefits for Nigeria Oil and Gas Sectors", The SIJ Transactions on Computer Science Engineering \& its Applications (CSEA), vol. 07, no. 04, pp. 01-07, 2019 Available: $10.9756 /$ sijcsea/v7i4/03010010202.

[7] O. Odeyemi and O. Ogunseitan, "Petroleum industry and its pollution potential in Nigeria", Oil and Petrochemical Pollution, vol. 2, no. 3, pp. 223-229, 1985. Available: 10.1016/s0143-7127(85)90218-2.

[8] NNPC, "Monthly Petroleum Information", Nigerian National Petroleum Corporation, Lagos, Nigeria, 1984.

[9] Amnesty International, "Nigeria: Hundreds of oil spills continue to blight Niger Delta", Amnesty.org, 2015. [Online]. Available:

https://www.amnesty.org/en/latest/news/2015/03/hundreds-ofoil-spills-continue-to-blight-niger-delta/.

[10] M. Thoms, "A freeze-sampling technique for the collection of active stream sediments used in mineral exploration and environmental studies", Journal of Geochemical Exploration, vol. 51, no. 2, pp. 131-141, 1994. Available: 10.1016/03756742(94)90014-0.

[11] NOSDRA, "Oil spill management in Nigeria: Challenges of pipeline vandalism in the niger delta region of Nigeria", National Oil Spill Detection \& Response Agency, Abuja, 2008.

[12] R. Snowden and I. Ekweozor, "The impact of a minor oil spillage in the estuarine Niger delta", Marine Pollution Bulletin, vol. 18, no. 11, pp. 595-599, 1987. Available: 10.1016/0025-326x(87)90279-7.

[13] B. Ordinioha and S. Brisibe, "The human health implications of crude oil spills in the Niger delta, Nigeria: An interpretation of published studies", Nigerian Medical Journal, vol. 54, no. 1, p. 10, 2013. Available: 10.4103/0300-1652.108887.

[14] E. Okonkwo, "Oil Spills in Nigeria: Are There Social and Economic Impacts?", International Oil Spill Conference Proceedings, vol. 2014, no. 1, p. 300289, 2014. Available: 10.7901/2169-3358-2014-1-300289.1.

[15] C. Nwoko, "Assessing the socioeconomic impacts arising from oil pollutions in the Niger Delta region of Nigeria: including proposals for solution", $\mathrm{PhD}$, Aalto University, 2014. 
[16] K. Nwajiaku-Dahou, "The political economy of oil and 'rebellion' in Nigeria's Niger Delta", Review of African Political Economy, vol. 39, no. 132, pp. 295-313, 2012. Available: 10.1080/03056244.2012.688805.

[17] A. Oyefusi, "Oil and the Probability of Rebel Participation Among Youths in the Niger Delta of Nigeria", Journal of Peace Research, vol. 45, no. 4, pp. 539-555, 2008. Available: $10.1177 / 0022343308091360$

[18] P. Nwilo and O. Badejo, "Oil Spill Problems and Management in the Niger DELTA", International Oil Spill Conference Proceedings, vol. 2005, no. 1, pp. 567-570, 2005. [Accessed 13 March 2016].

[19] S. Adelana and T. Adeosun, "Environmental pollution and remediation: challenges and management of oil Spillage in the Nigerian coastal areas", American Journal of Scientific and Industrial Research, vol. 2, no. 6, pp. 834-845, 2011. Available: 10.5251/ajsir.2011.2.6.834.845. 